\title{
Rummer DGI's ideologi plads til idræt?
}

Af Keld Brandt

»Jeg var til landsstaevne i Silkeborg. Der var mange mellemmenneskelige kontakter og en god stemning. Men der var forste showplads forbeholdt gymnastikken og verdensholdet og en anden showplads forbeholdt andre internationale hold henvist til baggården«.1

Denne udtalelse fra en iagttager ved DGI's landstævne i Silkeborg afspejler en dyb splittelse i Danske Gymnastik- og Idrætsforeninger (DGI), hvor citatet tyder på, at gymnastikken indtager en førerrolle ved landsstævnerne, mens de forskellige idrætter orienterer sig efter gymnastikkens værdigrundlag. I de offentlige iscenesættelser kan man iagttage en forskel mellem »første showplads « $\mathrm{i}$ forgården og »anden showplads « i baggården. DGI's selvbillede ser således ud til at hvile på en mytisk og dermed forvrænget kultur, der er spaltet mellem gymnastik og idræt. Det kniber med andre ord for idrætskulturerne at blive integreret i »moderkulturen i DGI «. Den bevidste del af DGI-kulturen viser sig i det fysiske kropslige møde på landsstævnerne, som nærmest er skræddersyet til gymnastikken, der i kraft heraf føler sig selvskreven til at fremtræde på hovedstadion, mens de $\varnothing$ vrige idrætskulturer ser til fra kulissen.

DGI fremstår som en organisation, der omfatter mangfoldige aktivitetsformer og idrætter som f.eks. agility, folkedans, fod- bold, gymnastik og budo. Spørgsmålet er imidlertid, om der kan identificeres kerneværdier, der binder de mange kropskulturer sammen i DGI, eller om det kun er få delkulturer, der reelt er beslægtede? Hvilke kropskulturer anser sig selv eller bliver anset som legitime bærere af den folkelige gymnastik- og idrætsbevægelse, og hvilke kulturer befinder sig ude i kulden? Organisatorisk afgrænsning og besindelse på organisationens identitet og virke er i sig selv en nødvendig proces. Hvis DGI kritikløst kunne rumme hvad som helst, ville det være vanskeligt at tale om en egentlig kulturel identitet. På den anden side må udtrykket folkelig unægtelig skabe nogle forventninger om, at DGI reelt vil være i stand til at rumme et reprasentativt udsnit af kvalitativt forskellige kropskulturer. Dette skisma betyder, at DGI skal kunne balancere på en knivsæg mellem forenede modsætninger ${ }^{2}$ som fordomsfrihed og kompromisløshed for at profilere sig som en folkelig organisation.

Disse spørgsmål diskuteres bravt i disse år, hvor man søger at opstille kriterier for, hvilken indflydelse forskellige aktivitetsformer i DGI bør have. I den forbindelse må det være oplagt at vurdere, hvilke kropskulturer i DGI der tillægges eller tiltager sig magt til at definere kriterier for succes i organisationen? Denne diskussion sætter fokus på, hvilke kulturer der legitimt »ejer« visionerne og sætter dagsordenen 
for, hvad der »bør« anses for at være henholdsvis rigtig og forkert adfærd i DGIsammenhæng. Landsstævnet i DGI kan betragtes som en offentlige arena, hvor mange kropskulturer har mulighed for at synliggøre og iscenesætte sig over for hinanden. I den forbindelse vil landsstævnet som ritual være et værdifuldt instrument til officielt at markere, hvilken prestige forskellige kropskulturers fremtræden bør nyde blandt fællesskabet i DGI.

\section{Boldspillere betragter gymnastikkens skue fra sidelinjen}

Lad os en kort stund kast blikket på, hvordan landsstævnet eksempelvis opfattes af en boldspiller. Per Jessen fra Nordjyllands Idrætshøjskole har i et tidligere debatindlæg på DGI's hjemmeside givet udtryk for sit syn som boldspiller på DGI's landsstævner:

»Landsstcevnet er noget stort for gymnasterne. Dels er det selvfølgelig en stor idratsfest, hvor det sociale har stor betydning, men det er også en slags gymnasternes OL. Det er deres udstillingsvindue, hvor de fär lejlighed til at vise deres fardigheder og mulighed for at prastere og konkurrere med andre gymnastikhold. Det er stedet, hvor der gives og søges ny inspiration, så gymnastikken hele tiden er i udvikling. For boldspillere er landsstcevnet helt klart et socialt modested, hvor resultaterne har meget lille vardi. Vi må vare oprigtige og sige, at vi ikke kommer til landsstavne for at prostere, udvikle os og søge ny inspiration. Det sker i specialforbundenes regi ${ }^{3}{ }^{3}$
Synspunktet tyder på et skel mellem gymnastikken og de $\varnothing$ vrige idrætter, som også organisationens navn Danske Gymnastikog Idratsforeninger tyder på. Skellet viser sig ved, at gymnastikken fremhoeves og udvikles, mens boldspillere betragter dette skue fra sidelinjen. Boldspillernes engagement i DGI-stævner adskiller sig tydeligvis fra turneringer i DIF's specialforbund. Udsagnet vidner desuden om, at hver enkelt form for kropsaktivitet har udviklet egne idealer for, hvordan de bedst kan udfolde, iscenesætte og udvikle sig. For boldspillere gøres dette åbenbart bedst i DIF-regi. Skyldes det, at DIF i kraft af historien tilbyder et stærkere felt ${ }^{4}$ for sport end DGI? Eller er det snarere fordi, DGI's landsstævner udgør en barriere for idrætsdyster, hvor sejr og nederlag er afgørende for vurderingen af sportens præstationer? Rummer DGI's ideologi plads til denne form for idrætsudøvelse? I benægtende fald er spørgsmålet prekært. Skal DGI's ideologi og de strukturer, der understøtter denne, justeres, eller skal idrætterne nægtes berettigelse under henvisning til de historisk betingede " givne forhold « og den hævdvundne ideologi?

Udbyttet af landsstævnet vurderes meget forskelligt, afhængigt af øjnene der ser og de vilkår for iscenesættelse, der bliver idrætterne til del. Gymnastikken er centralt placeret og kan høste et ganske betragteligt udbytte af landsstævnet, mens idrætterne først og fremmest kommer for at dyrke det sociale samvær. Det sociale element anses absolut for at være værdifuldt, men idrætternes kernevardier kommer tilsyneladende ikke til udtryk på en måde, der tillægges status og prestige på landsstævnets scene.

Analysen af landsstævnets struktur har vist, at landsstævnet ikke umiddelbart afspejler ligeværdighed og fælles værdier. Gymnastikken indtager en førerrolle på landsstævnet, mens de forskellige idrætter 
orienterer sig efter gymnastikkens værdigrundlag og undertrykker egne kerneværdier. Dette forhold er der egentlig ikke noget odiøst i, men i et oplysningsperspektiv må det være væsentligt, at der hersker fuld åbenhed om dette vilkår i DGI's kultur. I Grundtvigs oplysningsfilosofi spillede relationen lys og mørke samt liv og $d \phi d$ en helt central rolle og danner grundlag for en eksistentiel formel for succes i den folkelige gymnastik- og idrætsbevægelse. Formlen består $\mathrm{i}$ en cirkulær årsagssammenhæng mellem magt og synlighed, der skal sikre overlevelse og gunstige vilkår i organisationen. En anden formel lyder: De som har, skal mere gives. Landsstævnet kan i den forbindelse betragtes som et kollektivt interaktionsritual, ${ }^{5}$ hvor de kulturer, der behersker spillet om synlighed og magt, er i stand til at $\varnothing v e$ væsentlig indflydelse på, hvordan roller og positioner fordeles mellem de forskellige kropskulturer som et sæt færdigsyede valg.

Rutiner, vaner, ritualer og traditioner ser ud til at have en stærkt adfærds- og normstyrende indflydelse på DGI's liv og udvikling. De virker som »støttepædagoger «, der kan lette det moderne menneskes trang til at vælge og diskutere alting. Til gengæld er disse færdigsyede beslutningsstrukturer udemokratiske og virker bag om ryggen på deltagere i organisationens påbudte og »selvfølgelige « rituelle adfærdsformer. Ritualernes iscenesættelse er således ligesom smag noget, man normalt ikke diskuterer - »sådan er det bare«.

\section{Gymnastikken er den selvlysende sol $i$ landsstaevnets centrum}

Nogle kropskulturer er vokset op fra den folkelige gymnastik- og idrætsbevægelses barndom, mens andre siden er kommet til. Med traditionens magt in mente betyder det, at der internt i DGI skelnes mellem kropskulturer med førstefødselsret og adopterede. Denne skelnen illustreres bl.a. af denne udtalelse fra en foreningsleder i DGI:

»De nye aktiviteter og idratter må vise deres berettigelse blandt de gamle. Kernen er gymnasterne og skytterne i DGI. Sådan er der mange mennesker, der opfatter det $\ll$.

Skellet danner basis for, hvorvidt en kropsaktivitet placeres på landsstævnets belyste forscene på stadion eller gemt af vejen på mere ydmyge placeringer på bagscenen. ${ }^{6}$ Denne opsætning afspejler en selvforståelse, der helt bogstaveligt placerer gymnastikken i centrum, mens forskellige idrætter kredser omkring som drabanter i forskellig afstand, hvilket denne udtalelse fra en respondent bl.a. vidner om: »Mange andre aktiviteter vil også gerne ind på stadion, men traditionelt placeres man andre steder ${ }^{7}{ }^{7}$

Med gymnastikken som den selvlysende sol i centrum og idrætterne som planeter, der genspejler lyset fra gymnastikkens ideologi, bliver det i denne optik muligt at indfange en komplementær relation mellem, hvad sociologen Norbert Elias ville kalde for en legitim gruppe af etablerede og delvis legitime outsidere. ${ }^{8}$ Gruppen af outsidere nyder kun en begrænset og betinget accept. Problemet er, at denne gruppe både skal kunne spille rollen som normale og afvigere på de etablerede gruppers betingelser. Afvigerne må være påpasselige med at trække for store veksler på den tilsyneladende tolerance fra de etablerede og stille krav om særlige begunstigelser eller individuelle hensyn. Samtidig må outsider- 
ne undgå at afsløre det tabu, at der er forskel på de forskellige kropskulturers prestige og anerkendelse og »spille med på spillet« og opretholde en myte om en fællesskabskultur i DGI.

I forhold til denne analyse spiller den franske sociolog Pierre Bourdieus habitusog praktikteori en central rolle $i$ forsøget på at forstå de forskellige kropskulturers forudsætninger for at iscenesætte og udvikle sig på landsstævnerne. ${ }^{9}$ DGI's landsstævner er i undersøgelsen blevet betragtet som et socialt rum med relativt få felter, hvor de forskellige kropskulturer kan gøre sig gældende og iscenesætte sig. Som det bl.a. er fremgået af skellet mellem etablerede og outsidere, kan der iagttages helt forskellige forudsætninger for at blive påvirket og selv påvirke de normer for kropslig og symbolsk adfærd, feltets struktur foreskriver. De forskellige kropskulturer kan i mindre eller højere grad være tilpasset landsstævnets symbolske orden det vil her sige den orden, der tilkendegiver, hvilke typer idrætslig adfærd der er $\emptyset$ nskværdige i DGI. Den orden er på sin vis ganske vilkårlig - og dermed ikke naturnødvendig - men alt andet end tilfaldig. Der er tale om en skabt orden, der lader virkeligheden tage sig ud som noget objektivt givet eller selvfølgeligt. Denne effekt kalder Pierre Bourdieu for symbolsk vold. ${ }^{10} \mathrm{~Pa}$ grund af de etablerede gruppers udøvelse af symbolsk vold - med henvisning til traditionens magt - reproduceres der en rangordning af værdier, der er med til at klassificere forskellige »aktivitetsformer« ud fra moralske målestokke. Det mest ironiske i den forbindelse er, at outsiderne medvirker til deres egen deklassering og underkastelse ved at deltage $i$ spillet.

Landsstævnernes ritualiserede form, der bygger på gentagelser, er med til at ind- prente mindre toneangivende kropskulturer en erkendelse og accept af mere fremherskende kulturers legitimitet og interesser, uanset om denne erkendelse er i modstrid med deres egne interesser og behov. For de kulturer, der har magt til at forme landsstævnets felter, gælder det om at opnå anerkendelse af kropslige aktiviteter, de herskende kulturer i forvejen mestrer, og som tilsvarende markerer en vis afstand til konkurrerende kropskulturer. Der kan i denne sammenhæng iagttages stor forskel på gymnastikkens og de øvrige idrætters evne til at fungere, iscenesætte sig samt påvirke de »fælles « kulturelle opvisningsfelter. Man ser ikke store topopgør i fodbold til DGI's landsstævner. Kampe, hvor der kæmpes om point og kåres vindere, ser ikke ud til at være i høj kurs. I stedet fremhæves DGI's verdenshold, hvor æstetikken er sat i højsædet. Dette at konkurrere og bedømme efter point tillægges ingen eller måske snarere en negativ værdi i gymnastikkulturen i DGI. Hvor idrættens præstationer udmønter sig i sejr/nederlag, ser gymnastikken i DGI ud til at orientere sig efter forskellen mellem gode og dårlige indtryk, som de æstetiske fremførelser efterlader sig hos publikum.

\section{Positiv sarbehandling af gymnastik og medlemstunge idratter}

Trods denne forskel i orienteringer mellem gymnastik og idræt er DGI's organisatoriske prioriteringer af ressourcer og $\gg$ serviceeftersyn af aktivitetsudvalg « i høj grad præget af kvantitative målinger, der fungerer på samme måde som pointgivning. Netop kriteriet om kvantitet stiller de små aktivitetsformer i en ugunstig konkurrencesituation i kampen om indflydelse og res- 
sourcer, alene af den grund at små aktiviteter har vanskeligere ved at gøre sig synlige. De vil derfor sandsynligvis være relativt tyndt repræsenteret $\mathrm{i}$ amtsforeninger eller koncentreret i nogle ganske få. Men også medlemstunge idrætter, der traditionelt er udsprunget af den engelske sportsbevægelse, har vanskeligheder med at leve op til DGI's kvantitative krav om aktivitetsniveau og synlighed. Såvel »små« som »store« idrætter har haft problemer med at leve op til DGI's krav, men mens de små idrætters ressourcer er blevet reduceret, får de store tilført flere ressourcer. Der er således indført præcedens for »positiv særbehandling « af de store idrætter, selvom det må tilføjes, at der stilles krav om mærkbare og synlige resultater. Spørgsmålet er imidlertid, om de store idrætter på længere sigt råder over tilstrækkelig relevant »kulturel kapital« til at opfylde DGI's kvalitative mål på områder, der afspejler DGI-gymnastikkens ideologier og derfor ligger fjernt fra idrætternes iboende kerneværdier og traditionelle domæner? Med disse overvejelser vil det derfor være nærliggende at fundere nærmere over, hvilke aktivitetsformer i DGI, der har haft og fremover vil have størst held til at formulere DGI's officielle succeskriterier og dermed ikke blot sikre sig en gunstig position, men også præge hele idrætsorganisationens kurs?

\section{Reprasenterer verdensholdet hele DGI?}

DGI's verdenshold skal tilsyneladende repræsentere den folkelige gymnastik- og idrætsbevægelses ide, men holdet består udelukkende af elite-gymnaster fra DGI. Som udenforstående vil man uværgeligt få det indtryk, at DGI er en elitcer gymnastikorganisation. Man ser ingen andre krops- kulturer på DGI's verdenshold end gymnastikken, og på den baggrund må det være relevant at problematisere holdets repræsentative status. Hvor er det folkelige element blevet af? Iscenesættelsen af DGI's verdenshold illustrerer ganske godt en $m y$ te om DGI's folkelighed. Gymnastikken, der blot er en del af DGI's mangfoldige palet af kropskulturer, forstørres som detalje op til at repræsentere hele den folkelige gymnastik- og idrætsbevægelse. Dette element i de officielle iscenesættelser viser, at DGI's oplysningspraksis slår over i dens modsætning og skaber myten om en fælles gymnastik- og idrætsbevægelse. ${ }^{11}$ Forholdet mellem lys og mørke byttes om i relation til idealet om oplysning, idet det $\gg$ indre kulturelle liv« i DGI fortrænges fra de officielle begivenheders overflade. I stedet »taler« gymnastikkulturen med sin suveræne fremtræden på vegne af hele kulturen i DGI, mens idrætterne i deres ufrivillige fravær i princippet har fået mundkurv på.

Man kan spørge sig selv, om der her er tale om DGI's livsløgn? Svaret er ikke så simpelt endda og kan slet ikke besvares med begreber som lys/mørke og sandhed og løgn ud fra et krav om modsigelsesfrihed. I stedet er der tale om en raffineret simulering, der forførisk veksler mellem tilsynekomst og forsvinding, hvor DGI's selvbillede hverken er helt forkert eller helt rigtigt i mytens cocktail af sandhed og løgn. ${ }^{12}$ Myten om »den fælles kultur i DGI « - alias gymnastikkens ideologi bæres bl.a. igennem af landsstævnets konkrete organisering af tid og rum og verdensholdets status som symbol. Symbolerne formår bl.a. på én gang at fremstille DGI som en fælles kultur og samtidig demonstrere forskel i kropskulturernes moralske status og prestige, uden at det virker påfaldende. Myten skal således uafvidende legitimere gymnastikkens ideologi og 
førerstilling og få det historisk betingede forspring til at tage sig naturligt ud for ikke at åbne for en kritisk refleksion. Nok kan man tale om, at DGI lever på en livsløgn, men samtidig må man sige, at denne livsløgn i høj grad skaber objektive realiteter, der i kulturel henseende ikke blot afspejler, men også virkeliggør en dominansrelation mellem gymnastik og idræt. De objektive strukturer på landsstævnet demonstrerer rent faktisk, at gymnastikkulturen er mere væsentlig end de $\varnothing$ vrige delkulturer, uden at denne påstand lader sig modsige. Landsstævnet erobrer som ritual argumentationens fylde og virker foreskrivende blot ved at vare. ${ }^{13}$ Gymnastikken sætter ideologisk dagsordenen med en underforstået henvisning til den folkelige gymnastiks tradition. Idrætterne søger i store træk at tilpasse sig, fordi disse delkulturer ikke umiddelbart kan integrere sig kulturelt inden for rammerne af DGI's felter for udfoldelse og udvikling.

»Traditionens træge strukturer « styrer tilsyneladende adfærden på en ganske bestemt måde ved de officielle begivenheder i DGI. For idrætterne betyder det, at deres kerneværdier ikke kommer officielt til udtryk og bliver anerkendt i DGI-sammenhæng. I stedet må idrætskulturernes aktører spille roller, der er påført udefra og indskrevet kropsligt som rutinemæssig adfærd ved de officielle begivenheder. Der vil på denne måde opstå konflikt mellem en indre identitet, som de specifikke idrætter selv står inde for, og en ydre identitet, der påføres udefra. Den indre identitet opleves som agte, men kommer ikke til udtryk og bliver realiseret. Den påførte identitet, der udspringer af idrætternes samspil med og opslugning $\mathrm{i} »$ moderkulturen $\mathrm{i}$ DGI «, opleves som falsk, men den bliver virkeliggjort som påtvunget adfærdsnorm. Herved spaltes krop og sjæl i idrætskultu- rerne og kan i værste fald resultere i en usikker og diffus følelse af identitet samt en $»$ uengageret og rutinemæssig « adfærd ved DGI's fælles begivenheder. ${ }^{14}$ Landsstævnerne kunne ellers have været en oplagt mulighed for, at de forskellige kropskulturers »selvfortælling « dels kunne blive bekræftet, og dels kunne blive korrigeret af de $\varnothing$ vrige medlemmer af »DGI-familien «.

\section{Konklusion og perspektivering}

Resultatet af den mytiske praksis er, at DGI som helhed fremstår med en kultur, der både er præget af spaltning og fortrængning. Gymnastikken skiller sig ud fra idrætterne, og idrætterne selv skiller sig ud fra hinanden uden nævneværdig kulturel forankring i DGI-moderkulturen. Da gymnastikken har overtaget scenen, og idrætterne er blevet henvist til et liv i skyggen, er der samtidig tale om en fortrængning fra de fælles officielle begivenheders overflade, hvor de kulturelle møder finder sted. For den enkelte idrætskulturs identitetsdannelse betyder det bl.a., at den ikke opnår fornøden resonans, når den optræder $\mathrm{i}$ DGI-sammenhænge. Såfremt en idrætskultur ikke kan optræde offentligt i DGI-sammenhænge på en måde, der er konsistent med de værdier, denne selv finder væsentlige, vil der uundgåeligt skabes en distance mellem den indre indstilling og den ydre fremtoning.

Myten holder sammen på den kulturelle kompleksitet og de potentielle spændinger og gør det muligt for DGI som organisation at ignorere disse potentielle muligheder for forandring og dermed opsuge angst for opløsning. Ved at lægge et tågeslør over kulturelle modsætninger, konflikter og spændinger vil DGI's udvikling i fremtiden blive hæmmet af kræfter fra det »kul- 
turelt ubevidste «, som man af gode grunde ikke kan forholde sig til.

Problemet med konflikter, der ikke erkendes, er, at de binder ressuurcer og hindrer positive forandringer og udvikling af organisationen som helhed. Ved en $\emptyset$ get bevidstgørelse og en åben og ærlig konfrontation kan modsætningerne imidlertid forliges og integreres. Herved kan der skabes løsninger, der gennem fortløbende genforhandlinger sikrer en legitim kultur med en dynamisk stabilitet. Samtidig vil man gennem den reelle indflydelse opnå, at alle de kropskulturer, der er involveret $\mathrm{i}$ DGI, kan føle et agte medejerskab af DGI's værdier, kultur og organisation. For den førende kulturs, dvs. gymnastikkens, vedkommende vil en eventuel beslutning om at afgive hævdvundne privilegier med henvisning til »det fælles bedste« utvivlsomt opleves som et smertefuldt tab af grundlæggende værdier og de åbenlyse fordele, privilegier indebærer. Hvis denne barriere kan overvindes, vil DGI for alvor kunne blive kulturelt integreret og vinde

\section{Noter}

1. Udtalelse fra respondent i DGI, jf. interviewmateriale.

2. Her henvises der til K.E. Løgstrups begreb »forenede modsætninger«, jf. Løgstrup (1997), s. 183184.

3. Citat fra debatindlæg fra Per Jessen, Nordjyllands Idrætshøjskole på DGI's hjemmeside, dateret 17/6 1998.

4. Med felt menes der her et felt for udfoldelse, fremvisning og udvikling, hvilket kan ses som en tilpasning af Pierre Bourdieus feltteori. Se evt. Martin D. Munks afhandling, Livsbaner gennem et felt (Lund, 1999) for en uddybning af feltteorien.

5. Inspireret af Erwin Goffmanns begreb »interaktionsritualer«, jf. Goffmann (1967). Se desuden Goffmann (1959) og (1992). respekt for sin indtræden i en post-traditionel æra og leve op til en vision om folkelig oplysning.

På baggrund af analysen og de fremlagte argumenter i artiklen er det min overbevisning, at DGI's væsentligste udfordringer i fremtiden bør bestå i:

- At magte kulturel kompleksitet og fortløbende afbalancere modsætninger under hensyn til fællesskabet.

- At skabe gunstige miljøer for udvikling af kvalitet og toppræstationer i mange dimensioner og lag.

- At balancere aktivt mellem individuelle løsninger og kollektive hensyn.

- At respektere og sætte fokus på idrætternes og gymnastikkens særkende og integrere de forskellige delkulturer indbyrdes i den fælles organisationskultur i DGI.

- At skabe ligeværdige og differentierede udfoldelsesfelter ved fælles samlinger.

6. Opdeling i for- og bagscene har taget afsæt i respondenters oplevelser af landsstævnets forskellige måder at profilere bestemte aktivitetsformer på. I den forbindelse har det været oplagt, at perspektivere iagttagelsen med brug af Erwin Goffmanns dramaturgiske model for scenen, hvor den metaforiske distinktion »front stage « og »back stage« udtrykker en klar skelnen mellem, hvilke aktiviteter man vil fremhæve og eksponere, og de som man helst vil skjule. Jf. Goffmann (1992).

7. Citat fra respondent i DGI. Jf. interviewmateriale.

8. Med inspiration fra Norbert Elias og John L. Scotson (1994). De opererer her med en dominerende gruppe af etablerede og en gruppe af underprivilegerede, der bliver stigmatiseret af den dominerende gruppe.

9. Der henvises til Bourdieu: (1992) og (1977).

10. Jf. ibid. 
11. Perspektiveringen er inspireret af Theodor W. Adorno og Max Horkheimers (1971) dobbeltese vedr. oplysning og myte $\mathrm{i}$.

12. I refleksionerne om myte har jeg taget afsæt i Roland Barthes (1969).

13. Denne analyse bygger på Hans Georg Soeffners forståelse af ritualets virkemåde som performativ praksis, jf. Niels Kayser Nielsens (1997) fremstilling.

\section{Litteratur}

Allen, R.F. og C. Kraft, The Organizational Unconscious (New York, 1982).

Andersen, Heine og Lars Bo Kaspersen, Klassisk og moderne samfundsteori (Reitzel, 1996).

Argyris, C. og D.A. Schön, Organizational Learning (Mass., 1978.)

- Theory in Practice (San Francisco, 1974).

Arnold, Peter J., »The Aestetic Aspects of Being in Sport. The Performer's Perspective in Contrast to That of Spectator « I: Journal of the Philosophy of Sport, vol. 17 (1985).

Bale, John, Sport, Space and the City (London, 1993).

Baumann, Zygmundt, Culture as Praxis (London, 1973).

Barthes, Roland, Mytologier (København, 1969).

Bourdieu, Pierre, Distinction - a social critique of the judgement of taste (London, 1992).

- Kultur og kritik (Göteborg, 1984).

- Outline of a Theory of Practice (Cambridge, 1977).

- »Program for a Sociology of Sport« I: Sociology of Sport Jounal, nr. 5 (1988).

- Carter, Erica, James Donald og Judith Squires (red.), Spaces and Place. Theories of Identity and Location (London, 1993).

Cassierer, Ernst, Language and Myth (New York, 1946).

Cooper, J. og R.T. Croyle, »Attitude and Attitude Change« I: Annual Review of Psychology, vol. 35 (1984).

Danske Gymnastik- og Idrætsforeninger. Diverse handlingsplaner for landsaktivitetsudvalg.

- »Folkeoplysning, krop og dannelse«, Paper fra konference afholdt 23.-24. oktober 1997 i DGI-byen i København. Ved Jørgen Gleerup og Niels Kayser Nielsen (Vingsted, 1998).

- »Hvordan ser jeg som boldspiller på at deltage i et landsstævne, som er bygget op omkring gym-
14. Der er her gjort brug af R.D. Laings (1972) teorier om sjælelig spaltning. På samme måde som Anthony Giddens har jeg her modificeret teorien om individets spaltning og anvendt denne teori $\mathrm{i}$ forbindelse med kollektive fænomener i analysen af idrætskulturer.

nastik?« Debatindlæg af Per Jessen, Nordjyllands Idrætshøjskole, på DGI's hjemmeside den 17/6 1998.

- Udvalgsanalyser.

- Årsberetninger for landsaktivitetsudvalg.

Elias, Norbert og J.L. Scotson, The Established and the Outsiders (London, 1994 [1995]).

Festinger, L.A, A Theory of Cognitive Dissonance (New York, 1957).

Garfinkel, H., Studies in Ethnomethodology (Prentice-Hall, 1967).

Goffmann, Erwin, Interacting Ritual (New York, 1967).

- The Presentation of Self in Everyday Life (New York, 1959].

- Vore rollespil i hverdagen (København, 1992).

Hobsbawm, Eric og Terence Ranger (red.), The invented tradition (London, 1983).

Horkheimer, Max og Theodor W. Adorno, Oplysningens dialektik (København, 1971).

Jørgensen, Keld Gall, Semiotik (København, 1993).

Laing, R.D., Det spaltede selv - et eksistentialistisk studie af tilregnelighed og galskab (København, 1972). Oversat til dansk af Jørgen Lumbye og Vagn Sparre-Ulrich fra The divided self (Tavistok, 1969). Løgstrup, K.E., System og symbol (København, 1997). Nielsen, Niels Kayser, Krop og kulturanalyser - den levede og konstruerede krop (Odense, 1997).

- Stil og ballade (Odense, 1994).

Pages, M., »The Collective Unconscious and Social Change« I: T. Johnstad (red.), Group Dynamics and Society (Mass., 1981).

Tange, Jan Ove, Samfunnets idrett - en sosiologisk analyse av idrett som sosialt system, dets evolusjon og funksjon fra arkaisk til moderne tid (Oslo, 1997).

Turner, Victor, The Ritual Process (New York, 1982). 